\title{
The effects of low curing temperature on the properties of cement mortars containing nanosilica
}

\author{
Authors: \\ Katarzyna Skoczylas, \\ Master of Engineering, Department of Building Physics and Building Materials, Faculty of Civil Engineering \\ and Architecture, West Pomeranian University of Technology, Poland, e-mail: sk26276@zut.edu.pl; \\ Teresa Rucińska, \\ Assistant Professor, Department of Building Physics and Building Materials, Faculty of Civil Engineering \\ and Architecture, West Pomeranian University of Technology, Poland, e-mail:Teresa.Rucinska@zut.edu.pl
}

\begin{abstract}
This study presents the experimental results on the effects of curing temperature and nanosilica, on the compressive strength and absorbing properties of cement mortars. Two groups of mortars were prepared, with the first containing reference samples. The second group was modified with a nanosilica admixture by $3 \%$ of the weight of cement. The mortar specimens were cured in $20^{\circ} \mathrm{C}, 10^{\circ} \mathrm{C}$ and $5^{\circ} \mathrm{C}$ constant temperature environments. Compressive strength after $12 \mathrm{~h}, 1,2,7$ and 28 days, water absorption and capillary porosity were evaluated on a $40 \times 40 \times 40 \mathrm{~mm}$ prism. The results confirmed that a low curing temperature delays strength development in the early days of hydration and slows down the strength growth rate of mortars, with an increase in age. The incorporation of nanosilica has a positive effect in improving the mechanical properties of cement mortars cured at low temperatures. Additionally, nanosilica contributes to decreasing the porosity of the cement matrix, so that transport properties, such as open porosity and sorptivity, improve under all curing conditions.
\end{abstract}

Keywords: cold weather, curing temperature, nanosilica, cement mortars.

For citation: Katarzyna S., Rucińska T. The effects of low curing temperature on the properties of cement mortars containing nanosilica. Nanotehnologii v stroitel'stve $=$ Nanotechnologies in Construction. 2019, Vol. 11, no. 5, pp. 536-544. DOI: 10.15828/20758545-2019-11-5-536-544.

Machine-readable information on CC-licenses (HTML-code) in metadata of the paper

<a rel="license" href="http://creativecommons.org/licenses/by/4.0/"><img alt="Creative Commons License" style="border-width:0" src="https://i.creativecommons.org/l/by/4.0/88x31.png" / ></a $><$ br / > span xmlns:dct="http://purl.org/dc/terms/" href="http://purl.org/dc/dcmitype/Text" property="dct:title" rel="dct:type" $>$ The effects of low curing temperature on the properties of cement mortars containing nanosilica $</$ span $>$ by $<$ a xmlns:cc="http://creativecommons. org/ns\#" href="Nanotehnologii v stroitel'stve = Nanotechnologies in Construction. 2019, Vol. 11, no. 5, pp. 536-544. DOI: 10.15828/2075-8545-2019-11-5-536-544" property="cc:attributionName" rel="cc:attributionURL" $>$ Katarzyna S., Rucińska T.</a $>$ is licensed under a $<$ a rel="license" href="http://creativecommons.org/licenses/ by/4.0/">Creative Commons Attribution 4.0 International License $</$ a $>.<$ br $/>$ Based on a work at $<$ a xmlns:dct="http://purl.org/dc/terms/" href="http://nanobuild.ru/ en_EN/nanobuild-5-2019/" rel="dct:source" $>$ http://nanobuild.ru/en_EN/nanobuild-5-2019/</a $>.<b r />$ Permissions beyond the scope of this license may be available at $<$ x xmlns:cc="http://creativecommons.org/ns\#" href="Teresa.Rucinska@zut.edu.pl" rel="cc:morePermissions" $>$ Teresa.Rucinska@zut.edu.pl</a $>$.

The paper has been received by editors: 12.09.2019.

The paper has been received by editors after peer-review: 01.10.2019.

The paper has been accepted for publication: 02.10.2019. 


\title{
Влияние низких температур выдерживания на свойства цементных растворов, содержащих нанокремнезем
}

\author{
Авторы: \\ Катаржина Скочилас, \\ магистр инженерных наук, кафедра строительной физики и строительных материалов, \\ факультет гражданского строительства и архитектуры, Западнопоморский технологический университет, Польша, \\ e-mail: sk26276@zut.edu.pl;
}

Тереза Ручинска,

доцент, кафедра строительной физики и строительных материалов, факультет гражданского строительства и архитектуры, Западнопоморский технологический университет, Польша, e-mail: Teresa.Rucinska@zut.edu.pl

Резюме: В исследовании представлены результаты эксперимента по определению влияния температуры выдерживания и нанокремнезема на компрессионную прочность и на впитывающие свойства цементных растворов. Были подготовлены две группы растворов, с контрольными образцами в первой. Вторая группа была модифицирована добавкой нанокремнезема в количестве $3 \%$ от массы цемента. Образцы растворов выдерживались при температуре $20^{\circ} \mathrm{C}, 10^{\circ} \mathrm{C}$ и $5^{\circ} \mathrm{C}$. Прочность на сжатие после 12 часов, 1, 2, 7 и 28 дней, водопоглощение и капилярная пористость определялась на балочке $40 \times 40 \times 40$ мм. Результаты подтвердили, что низкие температуры выдерживания задерживают нарастание прочности на ранних стадиях гидратации и замедляют скорость твердения в растворах с увеличением срока выдерживания. Введение нанокремнезема способствует улучшению механических свойств цементных растворов, выдержанных при низких температурах. Более того, нанокремнезем позволяет снизить пористость цементной матрицы так, что переносные свойства - открытая пористость и сорбиционная способность - улучшаются при всех условиях выдерживания.

Ключевые слова: холодная погода, температура выдерживания, нанокремнезем, цементные растворы.

Для цитирования: Катаржина С., Ручинска Т. Влияние низких температур выдерживания на свойства цементных растворов, содержащих нанокремнезем // Нанотехнологии в строительстве. - 2019. - Том 11, № 5. - С. 536-544. - DOI: 10.15828/20758545-2019-11-5-536-544.

Машиночитаемая информация о CС-лицензиях (HTML-код) в метаданных статьи

$<$ a rel="license" href="http://creativecommons.org/licenses/by/4.0/" ><img alt="Creative Commons License" style="border-width:0" src="https://i.creativecommons.org///by/4.0/88x31.png"/></a $><$ br $/><$ span xmlns:dct="http://purl.org/dc/terms/" href="http://purl.org/dc/dcmitype/Text" property="dct:title" rel="dct:type" $>$ The effects of low curing temperature on the properties of cement mortars containing nanosilica $</$ span $>$ by $<$ a xmlns:cc="http://creativecommons. org/ns\#" href="Nanotehnologii v stroitel'stve = Nanotechnologies in Construction. 2019, Vol. 11, no. 5, pp. 536-544. DOI: 10.15828/2075-8545-2019-11-5-536-544" property="cc:attributionName" rel="cc:attributionURL">Katarzyna S., Rucińska T.</a $>$ is licensed under a $<$ a rel="license" href="http://creativecommons.org/licenses/ by/4.0/">Creative Commons Attribution 4.0 International License $</ \mathrm{a}>.<\mathrm{br} />$ Based on a work at $<$ a xmlns:dct="http://purl.org/dc/terms/" href="http://nanobuild.ru/ en_EN/nanobuild-5-2019/" rel="dct:source" $>$ http://nanobuild.ru/en_EN/nanobuild-5-2019/</a $>$. $<$ br $/>$ Permissions beyond the scope of this license may be available at <a xmlns:cc="http://creativecommons.org/ns\#" href="Teresa.Rucinska@zut.edu.pl" rel="cc:morePermissions" $>$ Teresa.Rucinska@zut.edu.pl</a $>$.

Статья поступила в редакцию: 12.09.2019.

Статья поступила в редакцию после рецензирования: 01.10.2019.

Статья принята к публикации: 02.10.201. 


\section{INTRODUCTION}

Th general, the properties of mortars and concretes are determined under controlled laboratory conditions, where the curing temperature is usually fixed at around $20^{\circ} \mathrm{C}$. In practice, buildings around the world are built in various conditions with temperatures ranging from the negative to very high ones. Dynamic developments in the construction industry and the implementation of modern reinforced concrete structures, requires the use of advanced concreting technologies. During concreting at negative temperatures it is important to protect the fresh concrete mix from freezing, so that chemical reactions between cement and water, which have a decisive impact on the strength of the concrete, can take place. According to the American Concrete Institute [1] cold weather is defined as a period when the average daily air temperature drops below $5^{\circ} \mathrm{C}$ for more than three successive days and stays below $10^{\circ} \mathrm{C}$ for more than one-half of any 24 hour period. Cold weather conditions can have adverse effects on the construction process and the construction elements must therefore be properly secured. As such, compliance with cold weather requirements is recommended. Cold weather can affect masonry, mortar, grout during construction and reinforced concrete constructions. Properly designed construction elements must be resistant to low temperatures during periods of cold weather. Concrete mix hardening tests have shown that at temperatures below $10 \mathrm{oC}$, concrete setting slows down rapidly. When the temperature drops to $0^{\circ} \mathrm{C}$, the hydration process practically disappears [2]. Water subjected to temperature changes, reaches its maximum density at $4^{\circ} \mathrm{C}$, with the fastest decrease in density being observed when the physical state changes at $0^{\circ} \mathrm{C}[3]$. When concrete freezes prior to setting, the mixing water contained within also freezes, thus increasing volume. The result is a a lack in the necessary water for the hydration process, thus delaying hydration; moreover, additional pores are formed after thawing. When concrete freezes during the setting process, the resulting ice crystals destroy new leaven bonds. Furthermore, the freezing of concrete after hardening and setting damages its microstructure, as a result of an increase in the volume of free water. An increase in temperature affects the hydration process by increasing reaction rates, thus resulting in higher early concrete strength. However, excessively accelerated hydration can result in the formation of a more porous microstructure, which can in turn negatively affect long-term strength [2]. It has been shown that there is an optimal temperature of $13^{\circ} \mathrm{C}$, at which maximum strength can be achieved for a given concrete age [4].

To improve the properties of concrete and mortars in cold weather, various additives and admixtures are used. Recently, nanomaterials have received significant attention from researchers and industry, in regard to their potential as concrete admixtures [5]. This is evidenced by the rapid increase in the amount of patents as well as by the availability of the first commercial products using this technology $[6,7]$. Among nanomaterials, nanosilica has gathered particular attention. Silica nanoparticles (NS) have a very small size; the minimum grain size of concrete components is respectively: sand - $1500000 \mathrm{~nm}$, quartz flour $-30000 \mathrm{~nm}$, silica dust $-\mathrm{m} 150 \mathrm{~nm}$, precipitated silica $-50 \mathrm{~nm}$, nanosilica $-5 \mathrm{~nm}$ [8]. Due to its much smaller size in relation to cement grains, nanoparticles are the "filler" created in the process of the hydration of voids. Nanosilica fills the pores between the calciumsilicate-hydrate $(\mathrm{C}-\mathrm{S}-\mathrm{H})$ gel particles, thickens microstructure and thus improves the mechanical properties of the structure formed $[9,10]$. Silica nanoparticles also exhibit pozzolanic properties; after the incorporation of pozzolanic material in concrete or mortar, the total calcium hydroxide $(\mathrm{CH})$ content decreases, with additional amounts of hydrated calcium silicates being formed in its place. As a result, the structure of the hardened material becomes more compact, leading to increased strength and durability [2]. Studies have showed that the addition of nanosilica particles to cement paste improves the composite cement microstructure [11]. In addition, NS exhibits a nucleating effect, which significantly accelerates the hydration process of cement [12]. It has been reported that even small dosages of NS can noticeably affect cement hydration [13]. Nanosilica has the largest specific surface at the smallest particle size [14] and small NS nanoparticles considerably reduce the flow ability of the cementitious matrix [15]. Studies on the viscosity of cement paste and mortar containing nanosilica, have proven that more water is required to maintain workability at a constant level [16]. Exceeding the NS content in a cement mixture can lead to undesired composite compaction and the creation of NS agglomerations, thus leading to a deterioration in the mechanical and durability performance of a composite. The effects of NS on the performance of cement-based composites has already been reviewed extensively [17, 18].

Up to date and extensive research has been undertaken in regard to the effect of nanosilica on the freeze-thaw resistance of specimens $[19,20]$. However, these measurements were performed on specimens cured in standardized curing conditions. Additionally, while many researchers have studied the effects of elevated curing temperatures on the properties of composites containing nanosilica $[21,22]$, the effects of low temperature curing on the mechanical and durability properties of NS-modified remain overlooked. This work is therefore aimed at characterizing the effects of low curing temperatures on the strength development and transport properties of cement mortars. In this study, plain (control) and NS-modified specimens were cured at the low temperatures of $5^{\circ} \mathrm{C}$ and $10^{\circ} \mathrm{C}$, with their properties compared with a specimen cured in standardized laboratory conditions of $20^{\circ} \mathrm{C}$. 


\section{MAIN PART}

\section{MATERIALS AND METHODS}

\subsection{Materials}

The cement mortars were prepared using rapidly hardening Portland cement - CEM I 42.5R (conforming EN 197-1), standardized ISO quartz sand (EN 196-1) with particle size $<2 \mathrm{~mm}$ and tap water. Nanosilica (NS) suspension containing $50 \mathrm{wt} \%$ of solid mass was also used, where the liquid phase of nanosilica suspension was used as a part of the mixing water. A scanning electron microscope (SEM) micrograph of the NS used is presented in Figure 1.

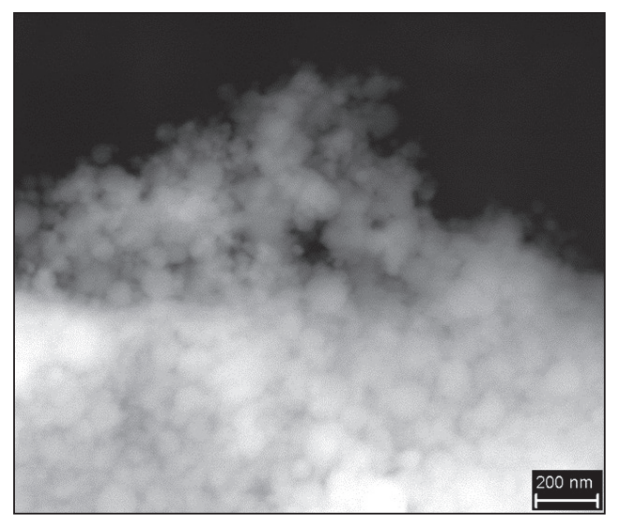

Fig. 1. SEM micrograph of nanosilica

\subsection{Mixture composition and mortar preparation}

Two groups of mortars were prepared: plain cement mortar (C) and NS-modified cement mortar containing $3 \%$ of NS admixture, by weight of cement. Cement mortars were prepared according to EN 197-1, with a cement:water:aggregate mass ratio equal to $1: 0.5: 3$. The amount of mixing water was proportionally reduced to the amount of water contained in the nanosilica suspension. The mixture compositions are presented in the table below:

Table.

Mixture compositions

\begin{tabular}{|l|}
\hline $\begin{array}{c}\text { Components } \\
\text { content }\end{array}$ \\
\hline Cement \\
\hline ISO sand \\
\hline Water \\
\hline Nanosilica \\
\hline
\end{tabular}

\begin{tabular}{|c|c|}
\hline \multicolumn{2}{|c|}{ Sample designation } \\
\hline $\mathrm{C}$ & NS \\
\hline 450 & 450 \\
\hline 1350 & 1350 \\
\hline 225 & 211,5 \\
\hline- & 27 \\
\hline
\end{tabular}

The specimens were prepared conforming to PN-EN 196-1, with the use of a standardized automatic mortar mixer. After mixing, molds were poured with fresh mortar and mechanically compacted. After being formed, the mortar specimens were cured in $20^{\circ} \mathrm{C}, 10^{\circ} \mathrm{C}$ and $5^{\circ} \mathrm{C}$ constant temperature environments. To obtain low temperature $\left(5^{\circ} \mathrm{C}\right.$ and $\left.10^{\circ} \mathrm{C}\right) \mathrm{CHL} 2$ and POL-EKO laboratory refrigerators were used.The temperature of $20^{\circ} \mathrm{C}$ was set in the climate chamber. The samples were named as follows: C5, C10, C20 for the control samples and NS5, NS10, NS20, for the samples with nanosilica. The digit next to the specimen name indicates the curing temperature.

\subsection{Test methods}

The samples were divided into 3 groups and kept at the appropriate temperatures of $20^{\circ} \mathrm{C}, 10^{\circ} \mathrm{C}$ and $5^{\circ} \mathrm{C}$, for up to 28 days of curing. Compressive strength was determined with $40 \times 40 \times 40 \mathrm{~mm}^{3}$ cubes after $12 \mathrm{~h}, 1,2,7$ and 28 days of curing, according to PN-EN 1015-11. Three cubes were used for each testing time, with the average being taken. Water absorption was determined after 28 days of curing on $340 \times 40 \times 160 \mathrm{~mm}^{3}$ prisms, according to ISO 52617 . Water absorption by partial immersion was determined by measuring the change in mass of the sample, the bottom of which had been in contact with water for a certain period of time. After 28 days the samples were removed from the refrigerators and aged for two weeks in natural conditions $\left(20^{\circ} \mathrm{C} \pm 2^{\circ} \mathrm{C}\right.$ with relative humidity $\left.\mathrm{RH}=50 \pm 5 \%\right)$. The samples were then wrapped with transparent tape and put in a box with water; mass was measured after $20 \mathrm{~min}$, $1 \mathrm{~h}, 2 \mathrm{~h}, 4 \mathrm{~h}, 8 \mathrm{~h}$ and $24 \mathrm{~h}$. Capillary porosity was determined using the water displacement method. To determine the dry mass, three samples of each case were oven-dried at $105^{\circ} \mathrm{C}$ until reaching a constant mass.

\section{RESULTS}

\subsection{Compressive strength}

Figure 2 present compressive strength after $12 \mathrm{~h}$ and $1,2,7,28$ days of curing. The strength growth rate of the mortars slowed down with an increase in age, because of the decrease in curing temperature. The curve inclination angle, in relation to the axis, is lower at lower temperatures. Compressive strength in the period from 7 to 28 days increased by only $1.5 \mathrm{MPa}, 4.9 \mathrm{MPa}$ and $5.9 \mathrm{MPa}$ for the control (C) samples, after curing at $5^{\circ} \mathrm{C}, 10^{\circ} \mathrm{C}$ and $20^{\circ} \mathrm{C}$, respectively. A comparable trend was observed with the NS specimens.

It can be seen that from the beginning of the hydration process, specimens containing NS exhibited a higher compressive strength than the corresponding reference specimens. At an age of $1 \mathrm{~d}$, the strength of the reference mortars at temperatures of $5^{\circ} \mathrm{C}$ and $10^{\circ} \mathrm{C}$ reached 


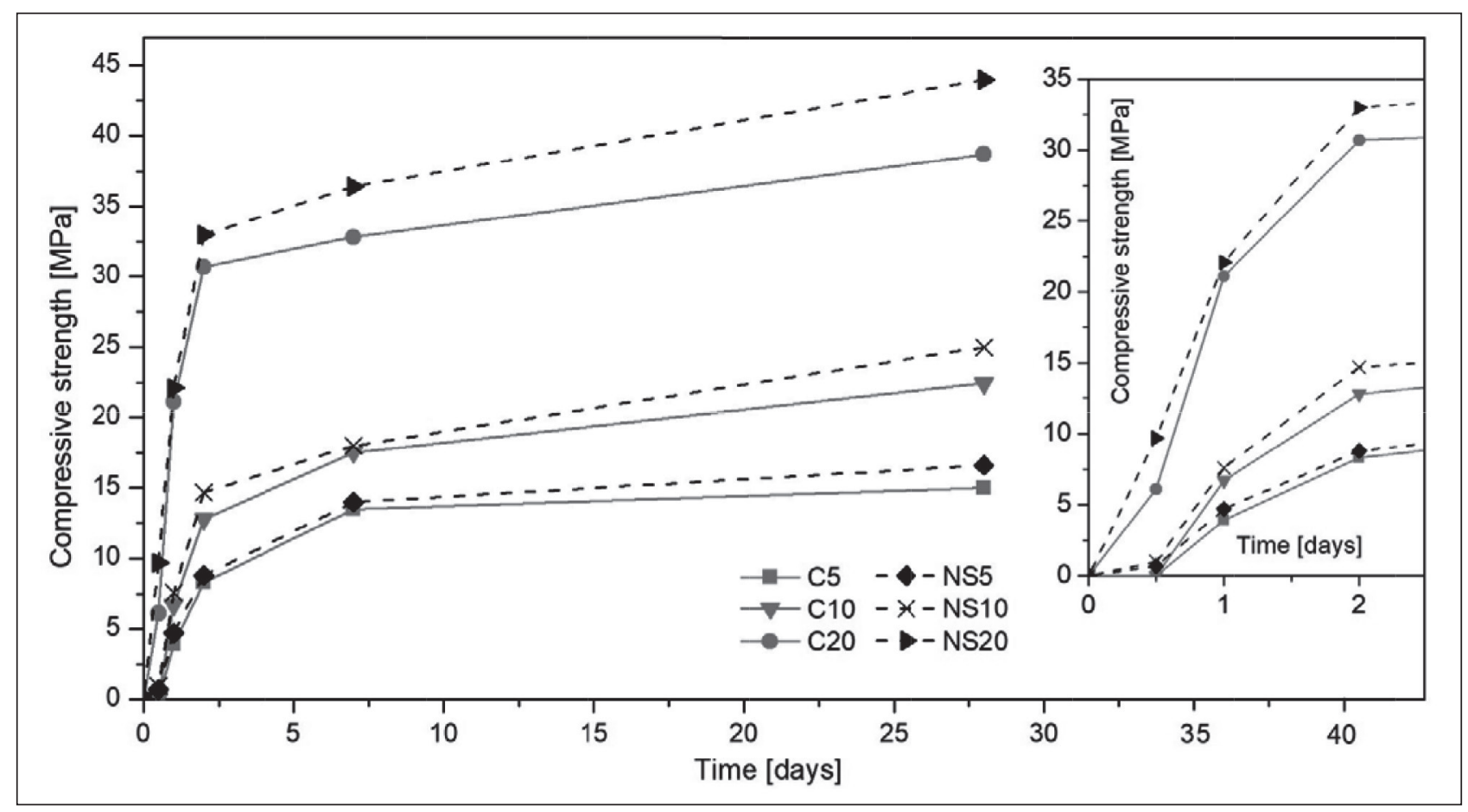

Fig. 2. Compressive strength of mortars after $12 \mathrm{~h}$ and 1, 2, 7, 28 days of curing

$18.2 \%$ and $31.7 \%$ (respectively), compared to the compressive strength of samples curing at the maintenance temperature of $20^{\circ} \mathrm{C}$. At an age of $2 \mathrm{~d}$ these values were $27.10 \%$ and $41.9 \%$ respectively, when cured at $5^{\circ} \mathrm{C}$ and $10^{\circ} \mathrm{C}$. After 7 days, the strength of the test mortars, under curing conditions of $5^{\circ} \mathrm{C}$ and $10^{\circ} \mathrm{C}$, reached $41.2 \%$ and $53.3 \%$ (respectively), compared to the compressive strength of samples curing at the maintenance tempera-

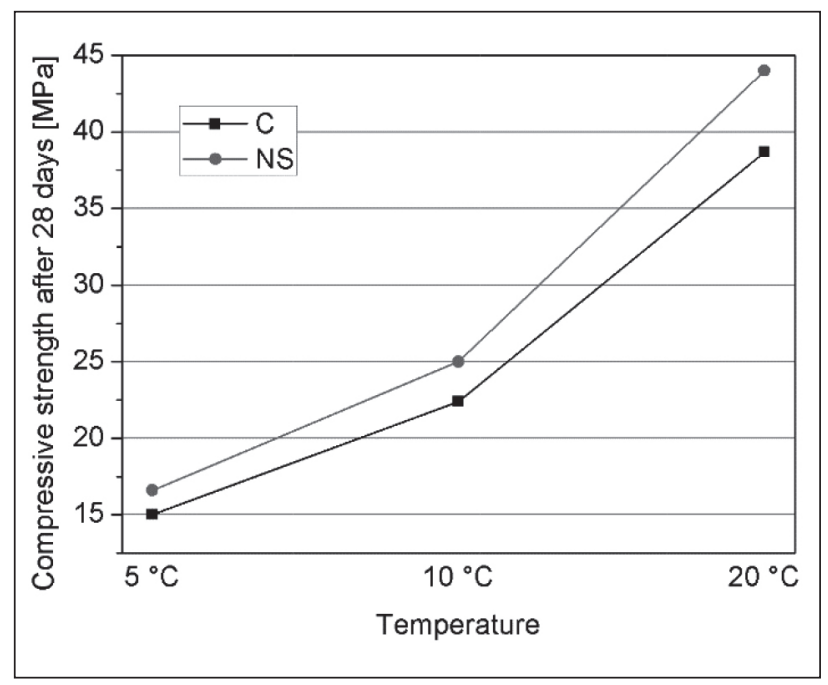

Fig. 3. The effects of curing at $5^{\circ} \mathrm{C}, 10^{\circ} \mathrm{C}$ and $20^{\circ} \mathrm{C}$ on compressive strength, after 28 days ture of $20^{\circ} \mathrm{C}$. The values presented were similar for mortars with $3 \%$ nanosilica admixture; the difference being that in this case it was also possible to test the 12-hour strength. Mortar cured at $5^{\circ} \mathrm{C}$ and $10^{\circ} \mathrm{C}$ reached $7.7 \%$ and $10.6 \%$, as compared to the compressive strength of samples curing at the maintenance temperature of $20^{\circ} \mathrm{C}$. The detailed results of the compressive strength tests, after 28 days of curing, are shown in Figure 3. Curing the samples at a temperature of $10^{\circ} \mathrm{C}$, instead of at $20^{\circ} \mathrm{C}$, resulted in a decrease in $28 \mathrm{~d}$ compressive strength by $42.2 \%$. In the case of samples cured at $5^{\circ} \mathrm{C}$, instead of at $20^{\circ} \mathrm{C}$, a $61.3 \%$ decrease in compressive strength was observed. A similar tendency has been reported in the literature [23], where the 28 day compressive strength decreased by approximately $25 \%$ when the concrete slab was cured at $0^{\circ} \mathrm{C}$, instead of at $20^{\circ} \mathrm{C}$.

Figures 4 and 5 show the ratios of tested mortar strengths at certain ages, in relation to 28 day strength. Control mortar samples $(\mathrm{C})$ without the addition of NS, were not hard enough after $12 \mathrm{~h}$ to test for compressive strength. Samples NS5 and NS10, cured at $5^{\circ} \mathrm{C}$ and $10^{\circ} \mathrm{C}$, reached approximately $4 \%$ of their 28-day compressive strength, while C20 and NS20 reached $16 \%$ and $22 \%$ of their 28 -day strength, respectively. It can be seen that after the first day, samples C5 and NS5 reached only 26-28\% of their 28-day compressive strength. For C10 and NS10, this value was slightly higher, reaching around 30\%. Samples C20 and NS20, cured under standard curing conditions, reached $55 \%$ and $50 \%$ of their 28 -day compressive strength, re- 


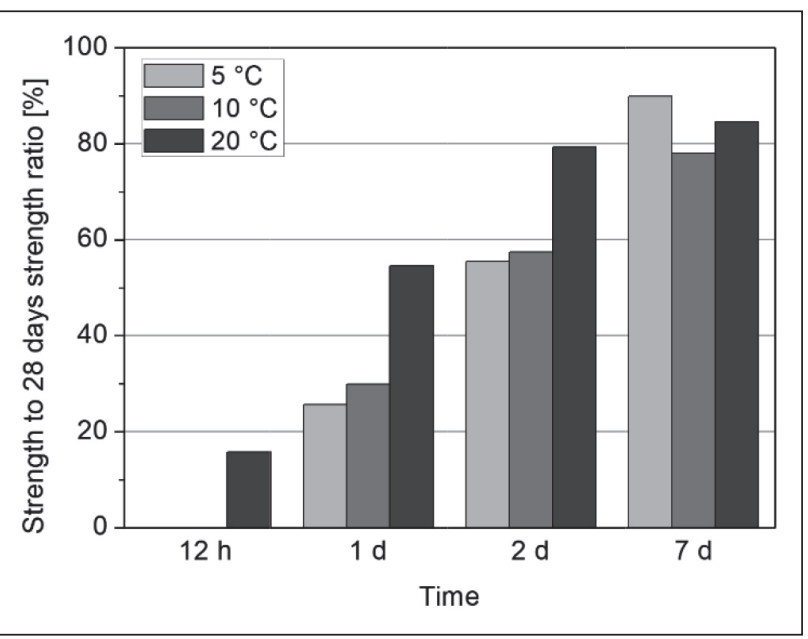

Fig. 4. Compressive strength to strength for 28 days ratio, control samples

spectively. On the second day of hydration, both mortars cured at $5^{\circ} \mathrm{C}$ and $10^{\circ} \mathrm{C}$ reached $53-59 \%$ of their 28 -day strength. In comparison, mortar samples C20 and NS20 reached $79 \%$ and $75 \%$ of their 28 -day strength, respectively. On day 7, the 28 day strength achieved at different temperatures begins to equalize. This means that low temperatures $\left(5^{\circ} \mathrm{C}\right.$ or $\left.10^{\circ} \mathrm{C}\right)$ delay strength development in the early days of hydration. It can also be seen that the incorporation of nanosilica had a positive effect on the mechanical properties of cement mortars, by compacting their structure and improving the bond between the aggregate and the cement matrix. Various studies have shown that the incorporation of NS in a mixture accelerates cement hydration and composite hardening; resulting in higher early strength $[7,19,24]$. This was also reflected in this study, through the possibility of determining the 12-hour compressive strength of NS-modified specimens, after curing at $5^{\circ} \mathrm{C}$ and $10^{\circ} \mathrm{C}$. Samples without the addition of nanosilica fell apart during the press test. In the case of samples cured at $20^{\circ} \mathrm{C}$, when $3 \%$ of NS was incorporated into the mixture, the compressive strength increased by $59.2 \%$ in comparison to the corresponding samples, after $12 \mathrm{~h}$ of curing. A significant influence of the admixture was observed in the case of samples cured at $5^{\circ} \mathrm{C}$, with a strength improvement of $22.9 \%$ after 1 day of curing, in comparison to the reference mortar. In the next days, the compressive strength increased by $6.2 \%, 3.4 \%$ and $10.5 \%$, respectively after 2 , 7 and 28 days of curing, in comparison to the reference mortar. In the case of samples cured at $10^{\circ} \mathrm{C}$, the strength improvement was $13.1 \%, 14.8 \%, 3.4 \%$ and $11.8 \%$, respectively, after 1, 2, 7 and 28 days of curing, in comparison to the reference mortar. In the case of samples cured at $20^{\circ} \mathrm{C}$, the incorporation of nanosilica caused a compressive strength increased by $13.7 \%$, in comparison to the corresponding samples, after 28 days of curing.

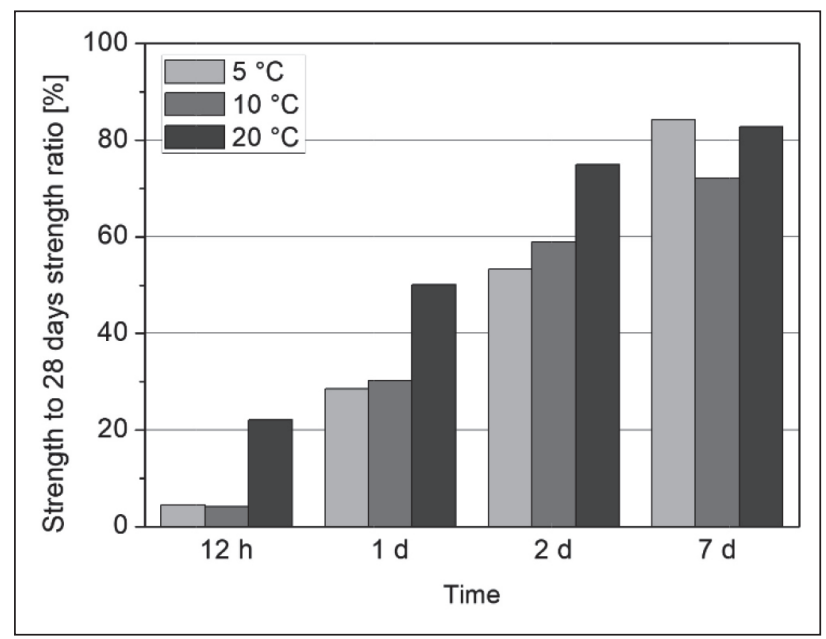

Fig. 5. Compressive strength to strength for 28 days ratio, NS samples

\subsection{Water absorption}

Figures 4 and 5 show the water absorption of the tested mortars. It can be seen that the water absorption rates in the first minutes of testing were significantly different and highly dependent on the curing conditions and the presence of NS. As the curing temperature increased, water absorption decreased. After 20 min of testing, the control samples curing at a temperature of $10^{\circ} \mathrm{C}$, instead of $20^{\circ} \mathrm{C}$, showed a more than double increase in the water absorption rate. In the case of control samples cured at $5^{\circ} \mathrm{C}$, instead of at $20^{\circ} \mathrm{C}$, the increase in the water absorption rate was over 3 times higher. This dependence decreased as time passed. After $24 \mathrm{~h}$ of testing, the water absorption rates of samples $\mathrm{C} 10$ and $\mathrm{C} 5$ were higher by $18.7 \%$ and $32.1 \%$, respectively, in comparison with mortar C20. A Comparable trend was observed with the NS specimens. After the first measurement, the water absorption rate of samples NS10 and NS5 was higher by $119.7 \%$ and $86 \%$, respectively, in comparison with mortar NS20. The water absorption ratio increased slowly with time, approaching the water absorption ratio of samples cured at lower temperatures. In the case of samples NS10 and NS5, the water absorption rate improvements after $24 \mathrm{~h}$ of curing were $27.4 \%$ and $37.4 \%$, respectively, in comparison with mortar NS20. Nanosilica should decrease water absorption because of its pore-filling effect and its ability to cause an improvement in microstructure. The effect of NS was present only in the first hours of testing. In the case of NS samples cured at $5^{\circ} \mathrm{C}$ and $10^{\circ} \mathrm{C}$, a decrease in the water absorption rate, by $20 \%$ and $6.7 \%$ respectively, was observed in comparison to the control samples. A different situation was observed in the case of samples cured at $20^{\circ} \mathrm{C}$. For sample NS20, the water absorption rate improvement was $47 \%$, in comparison to 


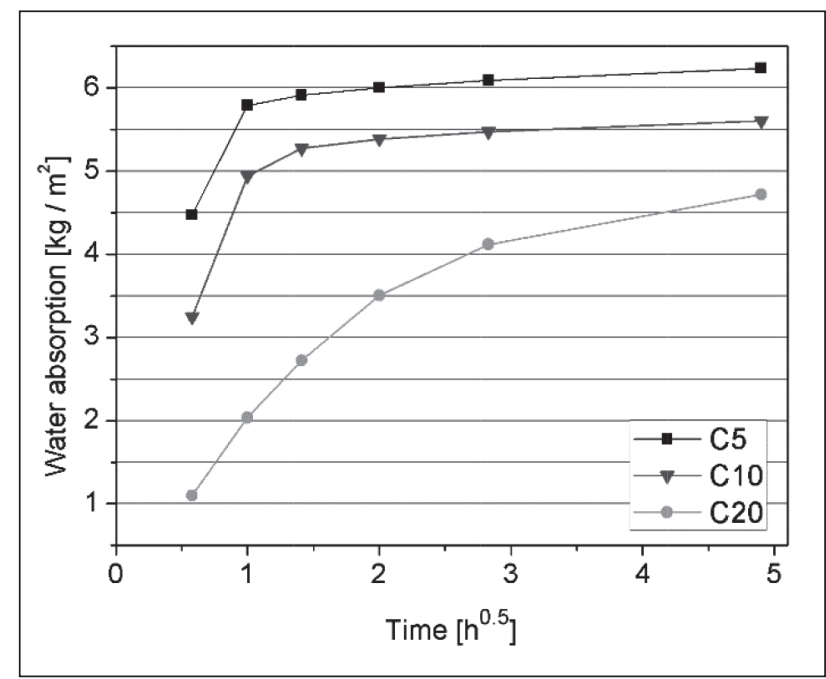

Fig. 6. Water absorption, $\mathrm{C}$ samples

sample C20. The values for the C and NS samples were similar after just 2 hours of testing. However, the final (24 h) sorptivity of NS20 was $4 \%$ lower in comparison to the $\mathrm{C} 20$ samples.

\subsection{Capillary porosity}

Figure 2 presents the capillary porosity of the cement mortars. Capillary porosity decreased as temperature increased. It can be seen that sample C5 had the highest capillary porosity values, with the rate of improvement being $11.5 \%$, in comparison to mortar C20. In the case of the NS mortars, the capillary porosity rate of sample NS5 was $7.2 \%$ higher than that of mortar NS20. There were slight differences in the capillary porosity of the mor-

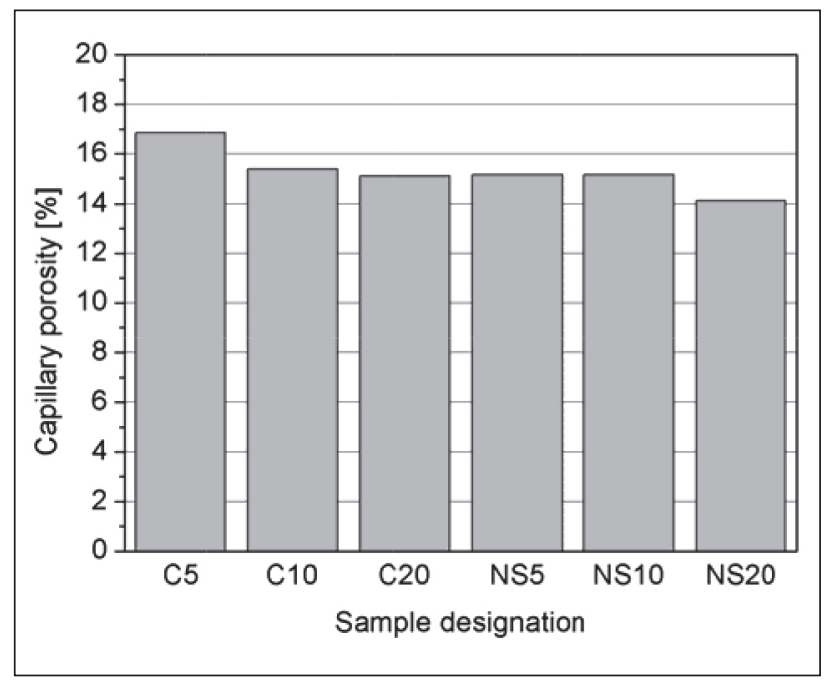

Fig. 8. Capillary porosity of cement mortars

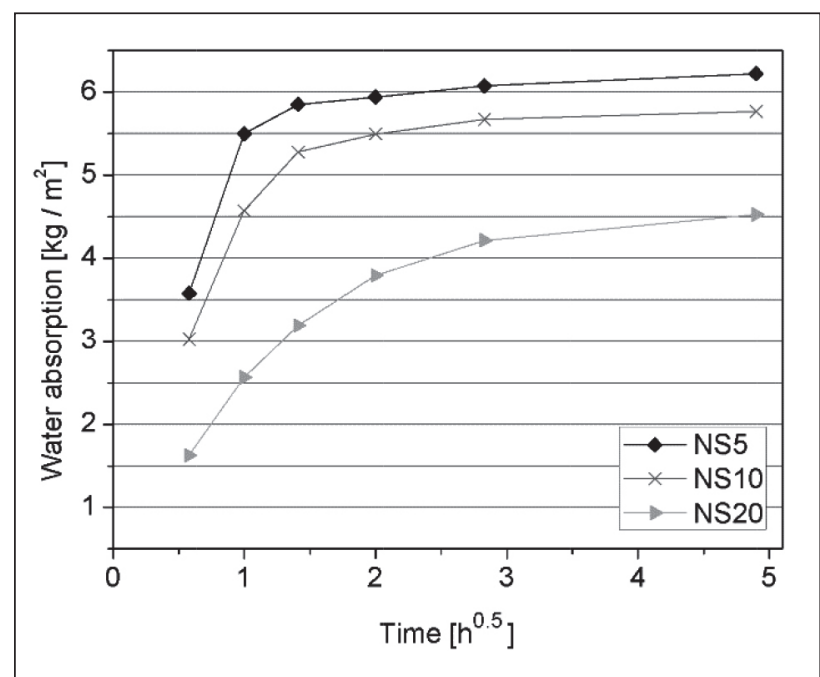

Fig. 7. Water absorption, NS samples

tars, depending on whether nanosilica was present. These results support the water absorption findings presented in the section above. Nanosilica refines the microstructure of cementitious composites, thus altering the pore structure of the cement matrix. Moreover, it makes the pore structure of the paste more homogeneous, by subdividing larger pores into smaller ones [25].

\section{CONCLUSION}

This paper has presented the effects of low curing temperature on the properties of cement mortars containing nanosilica. Based on the experimental results, we conclude that:

- Low curing temperature delays strength development in the early days of hydration and slows down the strength growth rate of the mortars, with an increase of age.

- Curing samples at temperatures of $10^{\circ} \mathrm{C}$ and $5^{\circ} \mathrm{C}$ was associated with a $42.2 \%$ and $61.3 \%$ loss of 28 day compressive strength, respectively.

- The incorporation of nanosilica has a positive effect on the mechanical properties of cement mortars, by accelerating the hydration process as well as refining microstructure. This was reflected through the possibility of determining the 12-hour compressive strength of NS-modified specimens, after curing at $5^{\circ} \mathrm{C}$ and $10^{\circ} \mathrm{C}$.

- Water absorption rates were highly dependent on curing conditions. Water absorption decreased as curing temperature increased.

- The incorporation of nanosilica contributes to a decrease in the porosity of the cement matrix; transport properties, such as open porosity as well as sorptivity, were thus improved in all curing conditions. 


\section{REFERENCES}

1. A ACI 306 Committee. Guide to cold weather concreting. ACI 306R-10, American Concrete Institute, Farmington Hills, Michigan, USA, 2010, $26 \mathrm{p}$.

2. Neville A.M., Properties of concrete, Longman, 1995.

3. Conciatori D., Brühwiler E. Water adsorption in concrete at low temperature. $2^{\text {nd }}$ International RILEM, Quebec City, Canada, September 11-15, vol. CD, 2006.

4. Klieger P. Effect of Mixing and Curing Temperature on Concrete Strength. Portland Cement Association, 1958.

5. Kropyvnytska T., Rucinska T., Ivashchyshyn H., Kotiv R., Development of Eco-Efficient Composite Cements with High Early Strength. CEE 2019: Proceedings of CEE, 2019, pp. 211-218.

6. Ivanov LA., Borisova O.N., Muminova S.R. The inventions in nanotechnologies as practical solutions. Part I, Nanobuild № 1-2019. DOI: 10.15828/2075-8545-2019-11-1-91-101.

7. Ivanov LA., Demenev A.V., Muminova S.R. The inventions in nanotechnologies as practical solutions. Part II, Nanobuild №2-2019. DOI: 10.15828/2075-8545-2019-11-2-175-185.

8. Czarnecki L. Nanotechnologia w budownictwie. Przegląd budowlany 1/2011, 2011, pp. 40-53.

9. Aggarwal P., Singh R.P., Aggarwal Y. Use of nano-silica in cement based materials-A review. Cogent Eng. 2015;2:1078018. DOI: dx.doi.org/10.1080/23311916.2015.1078018.

10. Potapov, V.V., Efimenko, Y.V., Gorev, D.S. Modification of concrete by hydrothermal nanosilica. Nanotehnologii v stroitel'stve. Nanotechnologies in Construction 2019, 11(3), pp. 248-265, DOI:10.15828/2075-8545-2019-11-3-248-265.

11. Krivenko P.V., Sanytsky M., Kropyvnytska T., The Effect of Nanosilica on the Early Strength of Alkali-Activated Portland Composite Cements. Solid State Phenomena (Volume 296), pp. 21-26.

12. Sikora P., Cendrowski K., Elrahman M.A., Chung S.Y., Mijowska E., Stephan D. The effects of seawater on the hydration, microstructure and strength development of Portland cement pastes incorporating colloidal silica. Applied Nanoscience, DOI: doi.org/10.1007/s13204-019-00993-8, 2019.

13. Sikora P., Elrahman M.A., Chung S.Y., Cendrowski K., Mijowska E., Stephan D. Mechanical and microstructural properties of cement pastes containing carbon nanotubes and carbon nanotube-silica core-shell structures, exposed to elevated temperature. Cement and Concrete Composites 95 (2019) pp. 193-204. DOI: doi.org/10.1016/j.cemconcomp.2018.11.006.

14. Geim A.K., Novoselov K.S. The rise of grapheme. Manchester Centre for Mesoscience and Nanotechnology, University of Manchester, 2007.

15. Zabihi N., Ozkul M.H. The fresh properties of nano silica incorporating polymer-modified cement pastes, Construction and Building Materials 168, 2018, pp. 570-579.

16. Senff L., Labrincha J.A., Ferreira João A.M., Hotza D., Repettee W.L. Effect of nano-silica on rheology and fresh properties of cement pastes and mortars. Construction and Building Materials, vol. 23, no. 7, 2009, pp. 2487-2491.

17. Sikora P., Elrahman M.A., Stephan D. The Influence of Nanomaterials on the Thermal Resistance of Cement-Based Composites-A Review. Nanomaterials 2018, 8, 465; DOI: doi:10.3390/nano8070465.

18. Shah S.P., Hou P., Konsta-Gdoutos M.S. Nano-modification of cementitious material: Toward a stronger and durable concrete. J. Sustain. Cem.-Based Mater. 2015, 5, pp. 1-22.

19. Skoczylas K., Rucińska T. Strength and durability of cement mortars containing nanosilica and waste glass fine aggregate. 206 CWB-3/2018, 2018, pp. 206-215.

20. Behfarnia K., Salemi N. The effects of nano-silica and nano-alumina on frost resistance of normal concrete. Constr. Build. Mater. 2013, 48, pp. 580-584.

21. Dai J., Wang Q., Xie C., Xie Z., Tian X., Lou X., Guo H. Effect of Curing Temperature on Activity Index of Silica Fume, Materials Science and Engineering, Volume 381, conference 1, 2018, DOI: doi:10.1088/1757-899X/381/1/012096.

22. Jun L., Yao L., Yuanquan Y., Yunpeng C. Effect of Low Temperature on Hydration Performance of the Complex Binder of Silica Fume-Portland Cement J. Wuhan Univ. Tech. 2014, pp. 175-81.

23. Nassif A.Y., Petrou M.F. Influence of cold weather during casting and curing on the stiffness and strength of concrete. Construction and Building Materials 44, 2013, pp. 161-167.

24. Chen Y., Deng Y-f., Li M-q. Influence of Nano-SiO on the Consistency, Setting Time, Early-Age Strength, and Shrinkage of Composite Cement. Advances in Materials Science and Engineering, Volume 2016, Article ID 5283706, 8 pages. DOI: dx.doi. org/10.1155/2016/5283706

25. Sikora P., Augustyniak A., Horszczaruk E., Rucinska T., Nawrotek P., Mijowska E. Characterization of Mechanical and Bactericidal Properties of Cement Mortars Containing Waste Glass Aggregate and Nanomaterials. Materials, 9(8)701, 2016, DOI: doi/10.3390/ma9080701. 


\section{INFORMATION ABOUT THE AUTHORS}

Katarzyna Skoczylas, Master of Engineering, Department of Building Physics and Building Materials, Faculty of Civil Engineering and Architecture, West Pomeranian University of Technology, Szczecin, Poland, e-mail: sk26276@zut.edu.pl;

Teresa Rucińska, Assistant Professor, Department of Building Physics and Building Materials, Faculty of Civil Engineering and Architecture, West Pomeranian University of Technology, Szczecin, Poland, e-mail:Teresa.Rucinska@zut.edu.pl

\section{ИНФОРМАЦИЯ ОБ АВТОРАХ}

Катаржина Скочилас, магистр инженерных наук, кафедра строительной физики и строительных материалов, факультет гражданского строительства и архитектуры, Западнопоморский технологический университет, Щецин, Польша, e-mail: sk26276@zut.edu.pl;

Тереза Ручинска, доцент, кафедра строительной физики и строительных материалов, факультет гражданского строительства и архитектуры, Западнопоморский технологический университет, Щецин, Польша, e-mail:Teresa.Rucinska@zut.edu.pl 